\title{
Sugar cane bagasse as feedstock for second generation ethanol production. Part I: Diluted acid pretreatment optimization
}

\author{
Gabriel J. Vargas Betancur \\ Laboratórios de Desenvolvimento de Bioprocessos \\ Departamento de Engenharia Bioquímica \\ Escola de Química, Centro de Tecnologia \\ Universidade Federal do Rio de Janeiro, Brasil \\ Nei Pereira Jr.* \\ Laboratórios de Desenvolvimento de Bioprocessos \\ Departamento de Engenharia Bioquímica \\ Escola de Química, Centro de Tecnologia \\ Universidade Federal do Rio de Janeiro, Brasil \\ E-mail: nei@eq.ufrj.br \\ Website: www.ladebio.org.br
}

Financial support: Brazilian Council for Research (CNPq) and Brazilian Oil Company Research Center (PETROBRAS).

Keywords: hemicellulose hydrolysis, severity factor, xylose.

Tons of sugar cane bagasse are produced in Brazil as waste of the sugar and ethanol industries. This lignocellulosic material is a potential source for secondgeneration ethanol production. Diluted acid hydrolysis is one of the most efficient pretreatments for hemicellulosic solubilization. The hydrolysate obtained is rich in xylose, which can be converted to ethanol by Pichia stipitis. This work used a statistical approach and the severity factor to investigate the effects of factors associated with the diluted acid hydrolysis process (acid concentration, solid:liquid ratio and time of exposure) on various response variables (xylose concentration, hydrolysis yield, inhibitor concentration and hydrolysate fermentability). The severity factor had a strong influence on the generation of inhibitors. The statistical analysis was useful for determining the effects of the individual factors and their interactions on the response variables. An acid concentration of $1.09 \%(\mathrm{vv})$, an $S: L$ ratio of $1: 2.8(\mathrm{~g}: \mathrm{ml})$, and an exposure time of 27 min were established and validated as the optimum pretreatment conditions for the generation of hydrolysates with high xylose concentration and low contents of inhibitors. In such conditions, hydrolysate with $50 \mathrm{~g} / \mathrm{l}$ of xylose was obtained.

Dependence on petroleum remains the most important factor affecting the worldwide distribution of wealth, global conflicts and the quality of the environment. Population growth and the associated demand for fuel and goods coupled with more restrictive environmental regulations have intensified the research and development of renewable energy feedstocks to substitute for and/or to complement fossil fuel sources (Pereira et al. 2008). Biotechnology offers alternatives for the development of the biomass industry based on lignocellulosic (LC) feedstocks for energy supply and the production of chemicals. A relatively new concept called the LC Biorefinery establishes a selective separation of residual biomass fractions and processes them in accordance with their chemical characteristics and the desired target products (Lynd et al. 2005). In this context, lignocellulosic materials, especially agroindustry residues, have been the subject of intense research since they are renewable sources of carbon and energy that are available in large quantities. The integrated and rational utilization of these abundant feedstocks can revolutionize a variety of industries, including liquid fuels, food, fodder and chemicals, and thereby bring immeasurable benefits, especially to countries with extensive regions of high biological productivity such as Brazil.

Sugar cane bagasse is the main Brazilian agroindustrial residue, being produced at approximately $250 \mathrm{~kg}$ per ton of sugar cane. In spite of the great potential of this residual biomass of lignocellulosic composition (60-70\% carbohydrates) for the production of fuels and chemicals, the majority of it is burned in sugar mills and alcohol distilleries for energy generation, and a smaller fraction is used for animal feeding; however there is still some surplus (Zanin et al. 2000; Wyman et al. 2005). Additionally, with the increase in cane production in response to the growth of global ethanol demand (from 66 to 125 million $\mathrm{m}^{3}$ between 2008 and 2020), more bagasse will be available (Pandey et al. 2000; Balat and Balat, 2009).

*Corresponding author 
Table 1. Levels for each factor in the experimental design.

\begin{tabular}{|c|c|c|c|c|c|}
\hline Factor & $\begin{array}{c}\text { Axial point } \\
(\mathbf{- a )}\end{array}$ & $\begin{array}{c}\text { Low } \\
\text { Level (-1) }\end{array}$ & Central level (0) & $\begin{array}{c}\text { High } \\
\text { level (+1) }\end{array}$ & $\begin{array}{c}\text { Axial point } \\
\mathbf{( + a )}\end{array}$ \\
\hline $\begin{array}{c}\text { Time of exposure } \\
\text { (min.) }\end{array}$ & 27 & 40 & 60 & 80 & 93 \\
\hline $\begin{array}{c}\text { Acid concentration } \\
\text { (\% vv) }\end{array}$ & 0.50 & 0.75 & 1.13 & 1.50 & 1.75 \\
\hline $\begin{array}{c}\text { Solid:liquid ratio } \\
\text { (g:ml) }\end{array}$ & $1: 3.3$ & $1: 3.0$ & $1: 2.5$ & $1: 2.0$ & $1: 1.7$ \\
\hline
\end{tabular}

Sugar cane bagasse is mainly composed of two polysaccharidic fractions (cellulose and hemicellulose) and a polyphenolic macromolecule (lignin). The more abundant component is cellulose (33-36\%), a polysaccharide consisting of a linear chain of several highly organized $\beta(1 \rightarrow 4)$-linked D-glucose units that generates crystalline regions and consequently increases resistance to the hydrolytic process. Hemicellulose is the second predominant fraction $(28-30 \%)$, and it possesses a heteropolysaccharidic composition that varies according to the source. Sugar cane bagasse hemicellulose is composed of heteroxylans, with a predominance of xylose, which is configured in a chain that can be chemically hydrolyzed more easily than cellulose. The polyphenolic fraction, called lignin, is a complex structure formed by the polymerization of aromatic alcohols that, when combined with the hemicellulose, covers the cellulose matrix, conferring resistance to enzymatic and chemical degradation (Sun and Cheng, 2002; Ververis et al. 2007).

For the integral utilization of lignocellulosic feedstock, it is necessary to develop a pretreatment process for the selective and efficient fractionation of its main polysaccharide components, which should undergo hydrolysis to generate a high concentration of sugar monomers. These sugar monomers can be used as substrates (building-blocks) for biotechnological and chemical processes (Mussato and Roberto, 2002).

The selective separation of hemicellulose can be performed using various pretreatments, such as ammonia fiber explosion (AFEX), alkaline humid oxidation (WAO), sodium hydroxide explosion (SHFEX), calcium hydroxide (Lime), Organosolv, steam explosion (STE), diluted acid hydrolysis (DAH) and liquid hot water (LHW) (Baudel et al. 2005; Mosier et al. 2005). Each pretreatment provides particular characteristics to the obtained phases, with the main purpose being to increase the susceptibility of the solid phase to enzymatic hydrolysis, and in some cases to make available the monomeric sugars of the hemicellulose. Among these treatments, acid hydrolysis stands out when compared with non-catalytic pretreatments because it allows for the generation of a liquid phase (hemicellulose hydrolysate) rich in xylose and with minor amounts of lignin derivatives that can inhibit cell metabolism relative to the levels seen with alkaline and organic pretreatments (Lavarack et al. 2002; Fogel et al. 2005; Gámez et al. 2006).

Additionally, xylose, the main hemicellulose-derived pentose, and hexose may be degraded during acid hydrolysis into furfural and 5-(hydroxymethyl) furfural (hydroxymethylfurfural), respectively, which are also reported to be inhibitors of cell metabolism (Balat et al. 2008).

This work aimed to characterize the individual effects of sulfuric acid concentration, solid:liquid (S:L) ratio and the time of exposure, as well as their synergic effects, on hydrolysate composition using severity factor expression and statistical approach. For this, a central composite design was constructed using response variables such as xylose concentration, concentration of inhibitors in the generated hydrolysates.

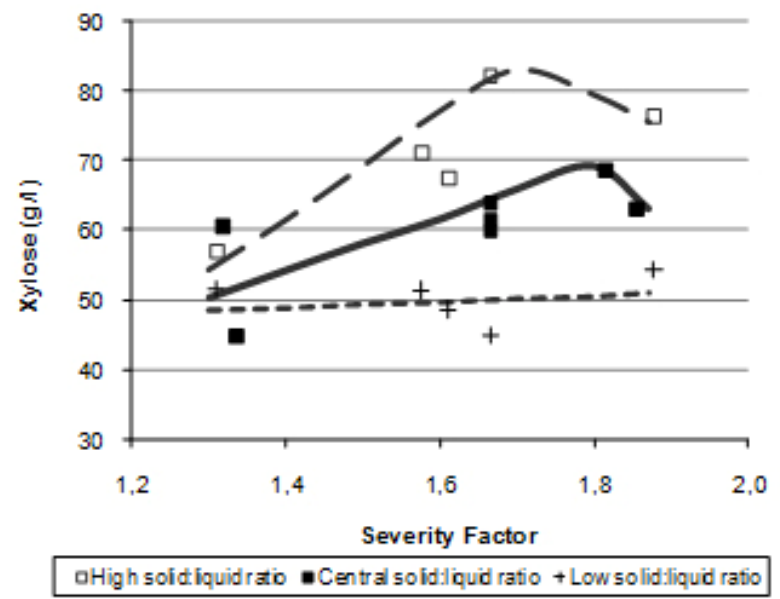

Figure 1. Xylose concentration resulting from the acid pretreatment as a function of the severity factor. 


\section{MATERIALS AND METHODS}

\section{Diluted acid pretreatment/hydrolysis}

The diluted acid hydrolysis was performed using a central composite design with the following factors: time of exposure, concentration of sulfuric acid and solid-liquid ratio. The temperature was kept constant at $121^{\circ} \mathrm{C}$. The level for each variable and the full experimental matrix expressed in coded values are shown in Table 1 and Table 2 , respectively.

After acid pretreatment, the liquid phase (hemicellulose hydrolysate) was separated from the solid by a pressure filter set within the reaction system (Santa Anna et al. 2007). Then, the $\mathrm{pH}$ of the liquid phase was adjusted to 6 by addition of $\mathrm{Ca}(\mathrm{OH})_{2}$, and the generated $\mathrm{CaSO}_{4}$ was separated by filtration. The liquid phase, called hemicellulose hydrolysate, had its sugar and inhibitor contents determined.

\section{Analytical methods}

Xylose concentration in the hydrolysates was determined by high performance liquid chromatography (HPLC) using an Aminex HPX-87P column (Bio-rad) maintained at $65^{\circ} \mathrm{C}$ and with a differential refractive index detector (Waters). Furfural, hydroxymethylfurfural and acetic acid concentrations were determined by HPLC using a KC811 column (Shodex) with a UV detector at $230 \mathrm{~nm}$ (Waters). The concentration of phenolic compounds was determined by the Folin-Ciocalteau method (Queiroz et al. 2002).

The hydrolysis factors were used to determinate the severity factor (Equation 1), as proposed by Schell et al. (2003), and its relation with the response variables was established. Additionally, the effects of each individual factor and its interactions were analyzed using the software STATISTICA 6.0 (StatSoft, 2002).

$$
\text { Severity factor }=\log _{10}\left(\text { time } \exp \left[\frac{\text { Temperature }-100}{14.75}\right]\right)-\mathrm{pH}
$$

\section{RESULTS AND DISCUSSION}

The experimental results for the diluted acid pretreatment are summarized in Table 3. The highest xylose concentrations (above $70 \mathrm{~g} / \mathrm{l}$ in experiments 5, 6 and 11) were achieved with the highest S:L ratio $(+\alpha$ or +1$)$. Other experiments carried out with high S:L ratios that resulted in low xylose concentrations were due to low acid concentration $(-1)$. On the other hand, experiments that provided the lowest xylose concentrations used either the lowest S:L ratio (experiments $3,4,7,8$ and 12) or the middle value (experiment 9) combined with the lowest acid concentration $(0.5 \%)$. These results show a strong influence of acid concentration and S:L ratio on xylose concentration,
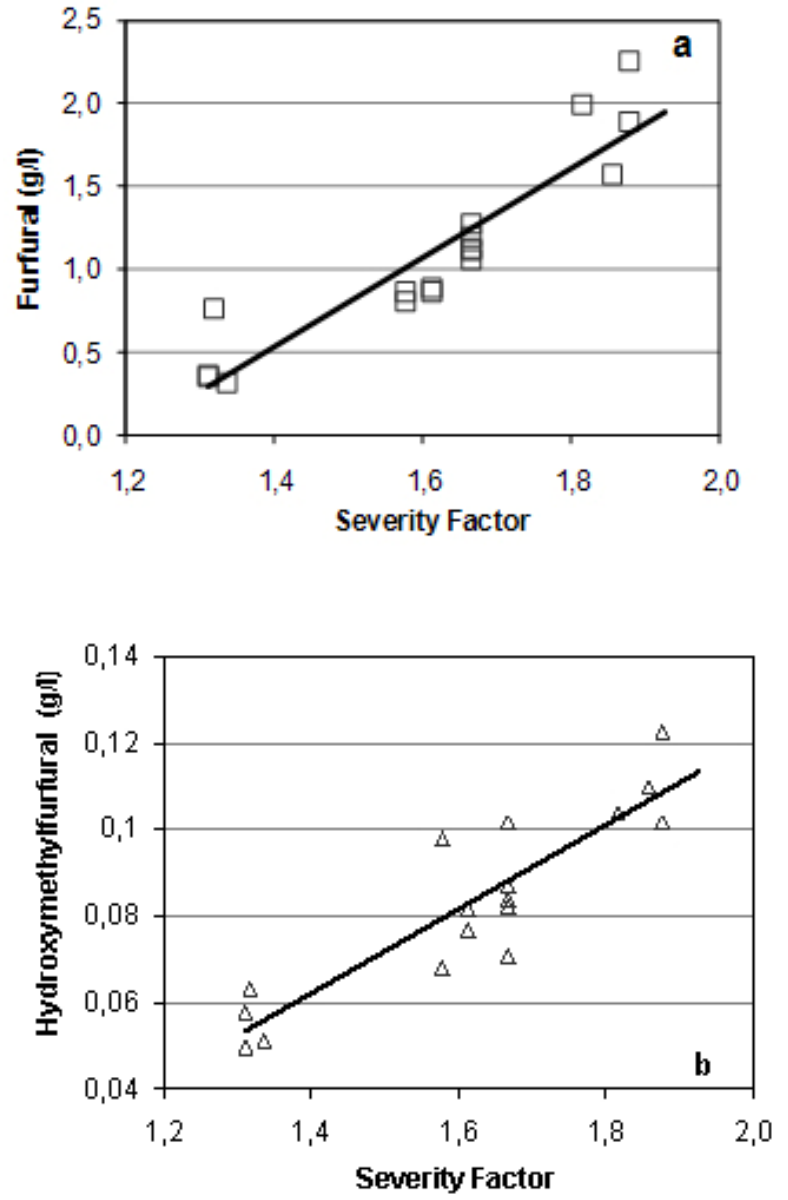

Figure 2. Furfural (a) and hydroxymethylfurfural (b) generated in acid pretreatment as a function of the severity factor.

as was reported by Cheng et al. (2008) for sugarcane bagasse and Ballesteros et al. (2008) for cardoon biomass.

Values ranging from $58.8 \%$ to $73.6 \%$ were observed for the hydrolysis yield, except for experiments 1 and 9, which resulted in values of $48.9 \%$ and $48.1 \%$, respectively, corresponding to the $-\alpha$ and -1 levels of acid concentration. Moreover, the highest (73.6\%) and the lowest (48.1\%) hydrolysis yields were achieved using the highest $(+\alpha)$ and the lowest $(-\alpha)$ acid concentrations, respectively, showing a directly proportional relation between acid concentration and hydrolysis yield.

The concentrations of furfural and hydroxymethylfurfural in the hydrolysates showed a strong dependence on acid concentration. Thus, the lowest concentrations of these furan compounds (experiments 1, 3 and 9) corresponded to low acid concentration ( $-\alpha$ and -1 ) while the maximum concentrations of these inhibitors were achieved (experiments 6, 8 and 10) when high acid concentrations were used $(+\alpha$ and +1$)$. Similarly, acetic acid concentrations were higher when high S:L ratios were used $(+\alpha$ and +1$)$. 
Table 2. Central composite design for the diluted acid pretreatment expressed in coded values.

\begin{tabular}{|c|c|c|c|}
\hline Experiment & Time of exposure & Acid concentration & Solid:Iiquid ratio \\
\hline 1 & -1 & -1 & +1 \\
\hline 2 & +1 & -1 & +1 \\
\hline 3 & -1 & -1 & -1 \\
\hline 4 & +1 & -1 & -1 \\
\hline 5 & -1 & +1 & +1 \\
\hline 6 & +1 & +1 & +1 \\
\hline 7 & -1 & +1 & -1 \\
\hline 8 & +1 & +1 & -1 \\
\hline 9 & 0 & $-\alpha$ & 0 \\
\hline 10 & 0 & $+\alpha$ & 0 \\
\hline 11 & 0 & 0 & $+\alpha$ \\
\hline 12 & 0 & 0 & $-\alpha$ \\
\hline 13 & $-\alpha$ & 0 & 0 \\
\hline 14 & $+\alpha$ & 0 & 0 \\
\hline 15 & 0 & 0 & 0 \\
\hline 16 & 0 & 0 & 0 \\
\hline 17 & 0 & 0 & 0 \\
\hline
\end{tabular}

Since the experimental conditions had a wide range, the experiments were assembled according to the $\mathrm{S}: \mathrm{L}$ ratio for a better understanding of the influence of the severity factor (which takes into account the acid concentration, time of exposure and temperature) on xylose concentration (Figure 1). Xylose concentration is dependent on the severity factor for high and intermediate $\mathrm{S}: \mathrm{L}$ ratios. Its maximum concentrations of $83 \mathrm{~g} / \mathrm{l}$ (high $\mathrm{S}: \mathrm{L}$ ratio) and $68 \mathrm{~g} / 1$ (intermediate $\mathrm{S}: \mathrm{L}$ ratio) were achieved with severity factors of 1.7 and 1.8, respectively. Increasing the severity factor further caused a decrease in xylose concentration. This is due to the dehydration of the released sugars to furan compounds (furfural from pentoses and hydroxymethylfurfural from hexoses), as described by Balat et al. (2008) and Lloyd and Wyman (2003). This reaction is more important as the experimental condition is more drastic, i.e., as the severity factor gets higher more furan compounds are generated (Figure 2).
Similarly to the xylose concentration, the hemicellulose hydrolysis yield varied with the severity factor (Figure 3). No defined tendency was observed between the severity factor and the concentration of phenolic compounds (values ranged from $1.5 \mathrm{~g} / 1$ to $2.3 \mathrm{~g} / \mathrm{l}$ ), nor with acetic acid concentration (values ranged from $4.4 \mathrm{~g} / \mathrm{l}$ to $11 \mathrm{~g} / \mathrm{l}$ ).

The statistical analysis showed the linear effect of the S:L ratio was the most important influence on the xylose concentration followed by the linear effect of the acid concentration (Figure 4a). No statistical significance $(p<$ 0.05 ) was observed for the interactions or the quadratic effects of this response variable. The positive effect of S:L ratio on xylose concentration indicates that high-xylose hydrolysates were obtained when high S:L ratios were used. Additionally, it should be noted that the magnitude of the linear effect of the S:L ratio, expressed in absolute value (16.98) was almost twice that of the linear effect of 


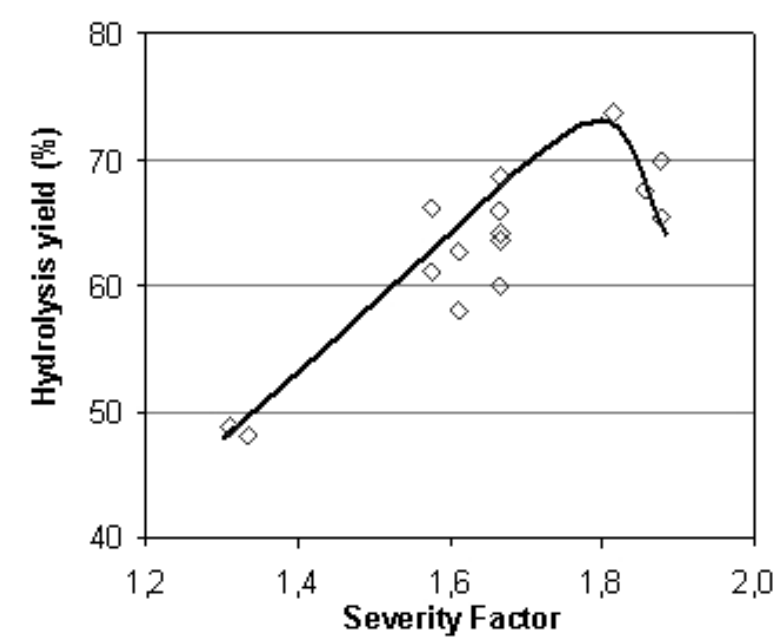

Figure 3. Hemicellulose hydrolysis yield of the acid pretreatment as a function of the severity factor for all experiments.

the acid concentration (9.03), and these were first and second in importance to xylose concentration, respectively.

In Figure 4b (Pareto chart for the hydrolysis yield) an opposite order in the importance of the factors can be observed. The linear effect of the acid concentration was the most important, followed by the linear effect of the S:L ratio, the magnitude of which was almost half that of the acid concentration. Again, only the linear effects of the acid concentration and $\mathrm{S}: \mathrm{L}$ ratio showed statistical significance $(p>0.05)$. Furthermore, the linear effect of the $\mathrm{S}: \mathrm{L}$ ratio on hydrolysis yield was negative, indicating that the use of low levels of this factor leads to a more effective extraction of xylose from the hemicellulosic fraction. Thus, the S:L ratio has opposite effects on xylose concentration and hydrolysis yield. In other words, to maximize xylose concentration a high $\mathrm{S}: \mathrm{L}$ ratio should be used and to maximize hydrolysis yield a low S:L ratio should be used.

For the acetic acid concentration, while no clear relation with the severity factor was noticed, statistical significance for all the individual effects was observed (Figure 4c). The linear effect of the S:L ratio was more important, which is reasonable since acetic acid arises from the hemicellulose component. The higher the S:L ratio is the more acetic acid is released into the hydrolysate.

The sulfuric acid concentration appears as the factor with greatest effect on the concentration of furfural and hydroxymethylfurfural generated by sugar degradation (Figure 4e and Figure 4f). For these response variables, the linear effect of the time of exposure was second in importance, and it was statistically significant for both $(p<$ 0.05 ). In addition, only the interaction of acid concentration with time of exposure and the linear effect of the S:L ratio

Table 3. Experimental design response variables for diluted acid hydrolysis.

\begin{tabular}{|c|c|c|c|c|c|}
\hline Experiment & Xylose & Hydrolysis yield & Acetic acid & Furfural & Hydroxymethyl-furfural \\
\hline 1 & 56.96 & 48.9 & 5.85 & 0.36 & 0.06 \\
\hline 2 & 67.53 & 58.0 & 7.40 & 0.89 & 0.08 \\
\hline 3 & 51.56 & 66.4 & 6.27 & 0,35 & 0.05 \\
\hline 4 & 48.64 & 62.6 & 5.57 & 0.86 & 0.08 \\
\hline 5 & 71.12 & 61.0 & 7.77 & 0.86 & 0.10 \\
\hline 6 & 76.25 & 65.4 & 11.00 & 2.25 & 0.12 \\
\hline 7 & 51.38 & 66.2 & 5.76 & 0.80 & 0.07 \\
\hline 8 & 54.31 & 69.9 & 5.80 & 2.00 & 0.10 \\
\hline 9 & 44.80 & 48.1 & 4.42 & 0.31 & 0.05 \\
\hline 10 & 68.63 & 73.6 & 6.54 & 2.00 & 0.10 \\
\hline 11 & 82.11 & 59.9 & 10.42 & 1.28 & 0.10 \\
\hline 12 & 44.87 & 63.6 & 5.40 & 1.06 & 0.07 \\
\hline 13 & 60.47 & 64.9 & 5.96 & 0.76 & 0.06 \\
\hline 14 & 63.04 & 67.6 & 6.82 & 1.57 & 0.11 \\
\hline 15 & 61.51 & 66.0 & 7.54 & 1.19 & 0.09 \\
\hline 16 & 63.91 & 68.6 & 7.68 & 1.11 & 0.08 \\
\hline 17 & 59.84 & 64.2 & 7.42 & 1.12 & 0.08 \\
\hline
\end{tabular}


showed statistical significance on furfural concentration, while the linear effect of the S:L ratio and the interaction of acid concentration with the S:L ratio showed statistical significance for hydroxymethylfurfural concentration.

The Pareto chart for phenolic compounds concentration (Figure 4d) indicates statistical significance only for the linear effect of the S:L ratio, with a positive influence. This result denotes constant extraction of the acid-soluble lignin in the range of the hydrolysis conditions evaluated.

A summary of the optimum level of each factor to maximize the performance of the diluted acid pretreatment is shown in Table 4. It became clear that high concentrations of sulfuric acid are necessary to obtain high xylose concentrations and hydrolysis yields during the

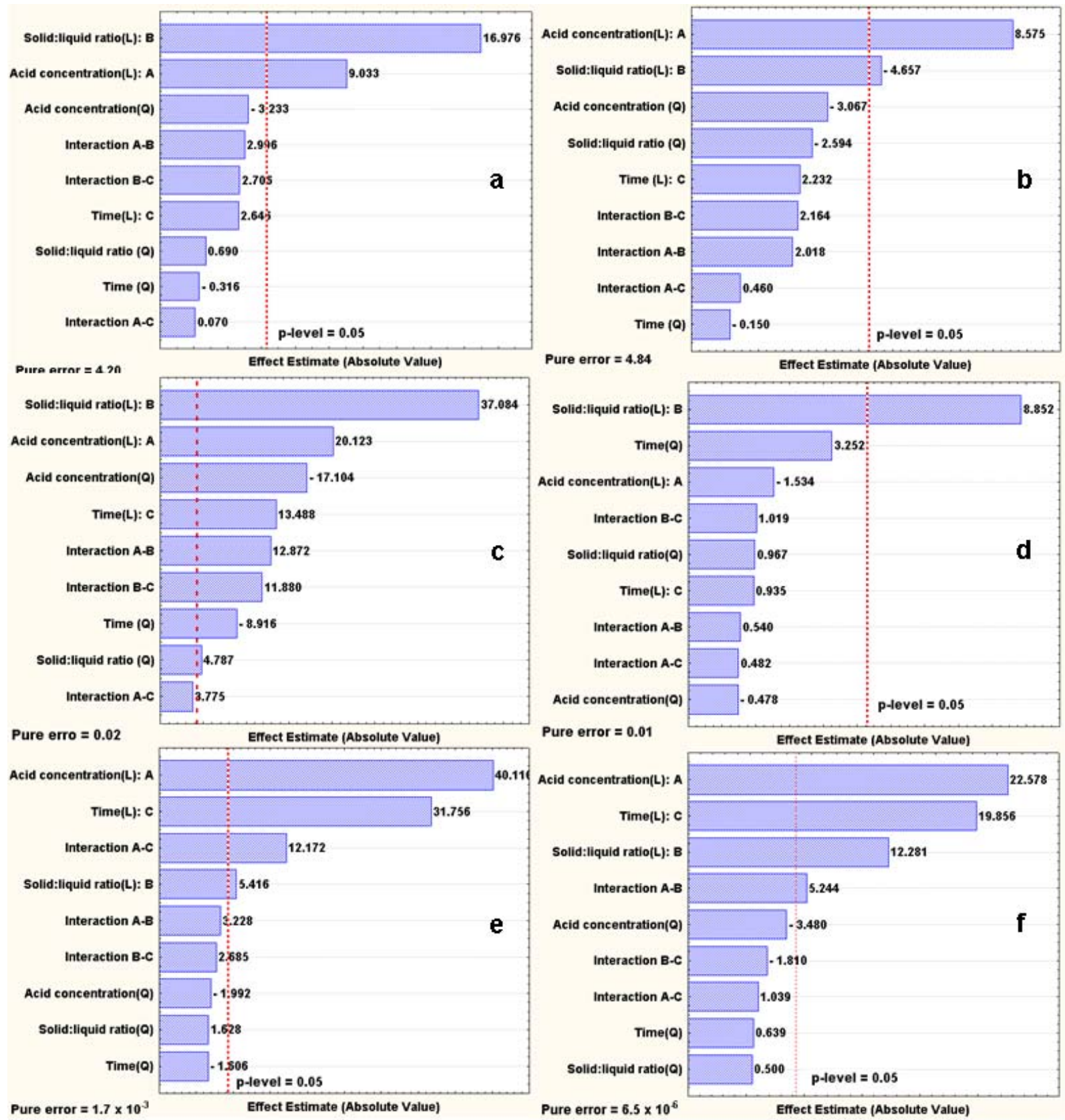

Figure 4. Pareto charts of standardized effects for (a) xylose (g/l); (b) hydrolysis yield (\%); (c) acetic acid (g/l); (d) phenolic compounds (g/l); (e) furfural ( $g / l)$ and (f) hydroxymethylfurfural $(g / l)$.

L: Linear effect.

Q: Quadratic effect. 
Table 4. Optimum levels of the acid pretreatment factors for all the response variables.

\begin{tabular}{|c|c|c|c|c|}
\hline \multirow{2}{*}{$\begin{array}{l}\text { Response variables for the } \\
\text { hydrolysis process }\end{array}$} & \multirow{2}{*}{$\begin{array}{l}\text { Optimization } \\
\text { criteria }\end{array}$} & \multicolumn{3}{|c|}{ Appropriated level } \\
\hline & & Acid concentration & Solid:liquid ratio & $\begin{array}{l}\text { Time of } \\
\text { exposure }\end{array}$ \\
\hline Xylose concentration & Maximize & ก & ก & $\bullet$ \\
\hline Hydrolysis yield & Maximize & ก & U & $\bullet$ \\
\hline Acetic acid concentration & Minimize & $\boldsymbol{U}$ & ע & $\mathbf{U}$ \\
\hline Furfural concentration & Minimize & $\boldsymbol{U}$ & $\mathbf{u}$ & $\boldsymbol{U}$ \\
\hline $\begin{array}{l}\text { Hydroxymethylfurfural } \\
\text { concentration }\end{array}$ & Minimize & $\mathbf{u}$ & $\mathbf{u}$ & U \\
\hline Phenolic compounds concentration & Minimize & $\bullet$ & U & $\bullet$ \\
\hline
\end{tabular}

กHigh levels, ULow levels, $\bullet$ No statistical significance

pretreatment step, yet a low acid concentration is also necessary for controlling the concentration of inhibitors.

Since high S:L ratios resulted in high concentrations of xylose and inhibitors, an ideal condition should be determined for obtaining a high substrate concentration and hydrolysis yield with low levels of inhibitors.

Empirical models for each response variable (Equation 2) were obtained and used to determine the conditions for achieving the best performance of the pretreatment hydrolysis. The models for the pretreatment response variables had good coefficients of determination $\left(R^{2} \geq\right.$ $0.83)$.

Response variable $=$

$\beta_{0}+\beta_{1}($ Acid concentration $)+\beta_{11}(\text { Acid concentration })^{2}$

$+\beta_{2}$ (Solid:liquid ratio) $+\beta_{22}$ (Solid:liquid ratio $)^{2}$

$+\beta_{3}($ time $)+\beta_{33}(\text { time })^{2}$

$+\beta_{12}$ (Acid concentration)(Solid:liquid ratio)

$+\beta_{13}$ (Acid concentration)(time)

$+\beta_{23}$ (Solid:liquid ratio)(time)

[Equation 2]

\section{$\beta$ : Empirical coefficient}

The pretreatment conditions yielding the best hydrolysis performance were determined using the desirability function (Equation 3) under the optimization criteria described in Table 4. The experimental results of the optimized conditions (Table 5) were within the predicted confidence intervals for almost all variables. The furfural, hydroxymethylfurfural and phenolic concentrations were not within the confidence interval but had close values.

$D=\left(d_{1}\left(Y_{1}\right) \times d_{2}\left(Y_{2}\right) \times \ldots \times d_{k}\left(Y_{k}\right)\right)^{1 / K}$

[Equation 3]

$D$ : overall desirability

$Y_{i}$ : Response variable

$\mathrm{d}_{\mathrm{i}}(\mathrm{Yi})=0$ for undesirable value and $d_{\mathrm{i}}\left(Y_{\mathrm{i}}\right)=1$ for desirable value

$k$ : number of response variables

Experiments were carried out to determined the hydrolysates fermentability (part II of this work) and further experiments will be done aimed at acclimatizing cells to hydrolysates containing high concentrations of the inhibitory substances generated during acid pretreatment.

\section{CONCLUDING REMARKS}

The severity factor had a very important influence on the xylose concentration and xylose yield, as well as on the generation of the inhibitors (furfural, hydroxymethylfurfural and acetic acid) during the diluted acid pretreatment. For some response variables, no relation with the severity factor could be established, which should be due to the absence of the S:L ratio in this expression. 
Table 5. Predicted conditions for process optimization and their experimental validation.

\begin{tabular}{|l|c|c|}
\hline \multicolumn{1}{|c|}{ Pretreatment conditions } & Predicted conditions \\
\hline Acid concentration $(\% \mathrm{vv})$ & 1.2 .8 \\
\hline S:L ratio $(\mathrm{g}: \mathrm{ml})$ & & 27 \\
\hline Time of exposition (min) & Predicted values & Experimental values \\
\hline \multicolumn{1}{|c|}{ Response variables for the hydrolysis process } & $54.61 \pm 4.20$ & 60.13 \\
\hline Xylose concentration (g/l) & $66.40 \pm 4.84$ & 6.04 \\
\hline Hydrolysis yield (\%) & $5.65 \pm 0.64$ & 0.55 \\
\hline Acetic acid concentration $(g / l)$ & $0.48 \pm 0.02$ & 0.09 \\
\hline Furfural concentration (g/l) & $0.05 \pm 0.01$ & 1.18 \\
\hline Hydroxymethylfurfural concentration $(g / l)$ & $1.92 \pm 0.39$ & \\
\hline Phenolic compounds concentration $(g / l)$ & & \\
\hline
\end{tabular}

The use of statistical analysis allowed the individual effect of every acid pretreatment factor on the characteristics of the hydrolysates. Also, the conditions dictated by the statistical analysis were validated experimentally, and the results were in good agreement with the predictions.

\section{REFERENCES}

BALAT, Mustafá; BALAT, Havva and ÖZ, Cahide. Progress in bioethanol processing. Progress in Energy and Combustion Science, October 2008, vol. 34, no. 5, p. 551573.

BALAT, Mustafá and BALAT, Havva. Recent trends in global production and utilization of bio-ethanol fuel. Applied Energy, November 2009, vol. 86, no. 11, p. 22732282.

BALLESTEROS, Ignacio; BALLESTEROS, Mercedes; MANZANARES, Paloma, NEGRO, M. José; OLIVA, J. Miguel and SÁEZ, Felicia. Dilute sulfuric acid pretreatment of cardoon for ethanol production. Biochemical Engineering Journal, 15 October 2008, vol. 42 , no. 1, p. $84-91$.

BAUDEL, Henrique M.; ZAROR, Claudio and de ABREU, César A.M. Improving the value of sugarcane bagasse wastes via integrated chemical production systems: an environmentally friendly approach. Industrial Crops and Products, May 2005, vol. 21, no. 3, p. 309-315.
CHENG, Ke-Ke; CAI, Bai-Yan; ZHANG, Jian-An; LING, Hong-Zhi; ZHOU, Yu-Jie; GE, Jing-Ping and XU, JingMing. Sugarcane bagasse hemicellulose hydrolysate for ethanol production by acid recovery process. Biochemical Engineering Journal, 15 January 2008, vol. 38, no. 1, p. 105-109.

FOGEL, Rafael; GARCIA, Rafaela R.; OLIVEIRA, Rebeca; PALACIO, Denise; MADEIRA, Luciana and PEREIRA Jr., Nei. Optimization of acid hydrolysis of sugarcane bagasse and investigations on its fermentability for the production of xylitol by Candida guilliermondii. Applied Biochemistry and Biotechnology, March 2005, vol. 122 , no. $1-3$, p. 741-752.

GÁMEZ, Sara; GONZÁLEZ-CABRIALES, Juan José; RAMÍREZ, José Alberto; GARROTE, Gil and VÁZQUEZ, Manuel. Study of the hydrolysis of sugar cane bagasse using phosphoric acid. Journal of Food Engineering, May 2006, vol. 74 , no. 1 , p. $78-88$.

LAVARACK, B.P.; GRIFFIN, G.J. and RODMAN, D. The acid hydrolysis of sugarcane bagasse hemicellulose to produce xylose, arabinose, glucose and other products. Biomass and Bioenergy, November 2002, vol. 23, no. 5, p. 367-380.

LLOYD, Todd and WYMAN, Charles E. Application of a depolymerization model for predicting thermochemical hydrolysis of hemicellulose. Applied Biochemistry and Biotechnology, March 2003, vol. 105, no. 1-3, p. 53-67. 
LYND, Lee R.; van ZYL, Willem H.; McBRIDE, John E. and LASER, Mark. Consolidated bioprocessing of cellulosic biomass: an update. Current Opinion in Biotechnology, October 2005, vol. 16, no. 5, p. 577-583.

MOSIER, Nathan; WYMAN, Charles; DALE, Bruce; ELANDER, Richard; LEE, Y.Y.; HOLTZAPPLE, Mark and LADISCH, Michael. Features of promising technologies for pretreatment of lignocellulosic biomass. Bioresource Technology, April 2005, vol. 96, no. 6, p. 673686.

MUSSATO, Solange Inês and ROBERTO, Inês Conceição. Produção biotecnológica de xilitol a partir da palha de arroz. Biotecnologia Ciência \& Desenvolvimento, September-October 2002, vol. 5, no. 28, p. 34-39.

PANDEY, Ashok; SOCCOL, Carlos R.; NIGAM, Poonam E. and SOCCOL, Vanete T. Biotechnological potential of agro-industrial residues. I: sugarcane bagasse. Bioresource Technology, August 2000, vol. 74, no. 1, p. 69-80.

PEREIRA Jr., Nei; COUTO, Maria Antonieta P.G. and SANTA ANNA, Lidia Maria M. Series on biotechnology: Biomass of lignocellulosic composition for fuel ethanol production within the context of biorefinery. Rio de Janeiro, Amigadigital press, 2008. 47 p. ISBN 978-85-903967-3-4.

QUEIROZ, Carla Regina Amorim dos Anjos; LEMOS, Sérgio Antônio de Morais and Do NASCIMENTO, Evandro Afonso. Caracterização dos taninos da aroeirapreta (Myracrodruon urundeuva). Revista Árvore, JulyAugust 2002, vol. 26, no. 4, p. 485-492.

SANTA ANNA, Lídia Maria Melo; PEREIRA Jr, Nei; VARGAS BETANCUR, Gabriel Jaime; BEVILAQUA, Juliana Vaz; GOMES, Absai da Conceição and MENEZES, Emerson Pires. Processo de produção de etanol a partir do hidrolisado da fração hemicelulosica do bagaço de cana-deaçúcar em reator do tipo presa. Instituto Nacional de Propriedade Industrial, 2007, patent PI 0505299-9, Brasil.

SCHELL, Daniel J.; FARMER, Jody; NEWMAN, Millie and McMILLAN, James D. Dilute-sulfuric acid pretreatment of corn stover in pilot-scale reactor. Applied Biochemistry and Biotechnology, March 2003, vol. 105, no. 1-3, p. 69-85.

STATSOFT, Inc. STATISTICA (data analysis software system), version 6.0. Available from Internet: www.statsoft.com. Statsoft, Inc., 2002.

SUN, Ye and CHENG, Jiayang. Hydrolysis of lignocellulosic materials for ethanol production: a review. Bioresource Technology, May 2002, vol. 83, no. 1, p. 1-11.

VERVERIS, C.; GEORGHIOU, K.; DANIELIDIS, D.; HATZINIKOLAOU, D.G.; SANTAS, P.; SANTAS, R. and CORLETI, V. Cellulose, hemicelluloses, lignin and ash content of some organic materials and their suitability for use as paper pulp supplements. Bioresource Technology, January 2007, vol. 98, no. 2, p. 296-301.

WYMAN, Charles E.; DALE, Bruce E.; ELANDER, Richard T.; HOLTZAPPLE, Mark; LADISCH, Michael R. and LEE, Y.Y. Coordinated development of leading biomass pretreatment technologies. Bioresource Technology, vol. 96, no. 18, December 2005, p. 1959-1966.

ZANIN, Gisella M.; SANTANA, Cesar C.; BON, Elba P.S.; GIORDANO, Raquel C.L.; De MORAES, Flavio F.; ANDRIETTA, Silvio R.; De CARVALHO NETO, Carlos Coelho; MACEDO, Isaias C.; FO, Djalma Lahr; RAMOS, Luiz P. and FONTANA, José D. Brazilian bioethanol program. Applied Biochemistry Biotechnology, March 2000, vol. 84-86, no. 1-9, p. 1147-1161. 